\title{
PENGARUH CITRA MEREK DAN KEPERCAYAAN KONSUMEN TERHADAP MINAT PEMBELIAN SECARA ONLINE
}

\author{
Zakky Zamrudi \\ E-mail: zzakky@gmail.com \\ Universitas Islam Kalimantan (UNISKA) MAB Banjarmasin
}

\begin{abstract}
Technological developments are very rapid nowadays and make it easier for people to communicate, which one of them is social network sites. The benefit of this platform is the ease to disseminate information both for commercial and communication purposes. This study aims to determine the interaction between users of instagram as one of the largest of social interaction provider nowadaysparticularly on the brand image and their trust in buying intention. The study involved 99 randomly selected people. The results of this study indicate that there are significant interactions between variables either directly or indirectly.
\end{abstract}

Keyword: SNS, instagram, GSCA, online-interaction, researchgram

\section{PENDAHULUAN}

Interaksi media sosial tumbuh pesat sebagai alternatif komunikasi dalam masyarakat kontemporer. Hal ini memungkinkan orang untuk melakukan komunikasi virtual melalui situs jejaring sosial. Dalam hal jejaring sosial, yang terbesar saat ini adalah raksasa facebook, diikuti oleh instagram dan yang terakhir adalah twitter (statista.com 2015).

Dengan adanya interaksi sosial ini menjari menarik karena juga terjadi proses jual beli secara online. Sisi menarik dari jual beli online ini adalah dimana sang pembeli cenderung tidak mengetahui bagaimana wujud asli dari barang yang akan dibeli. Jadi konsumen hanya akan disuguhkan dengan pencitraan virtual seperti gambar, gambar bergerak (vidio), dan juga suara dari suatu produk.

Dengan tidak adanya wujud fisik ini apakah konsumen masih akan mempertimbankan citra merek secara online dan kepercayaan konsumen itu sendiri ketika mereka akan membeli suatu produk.

Dari hasil penelitian yang sudah ada menunjukkan bahwa pada dasarnya 
secara signifikan citra merek dan kepercayaan konsumen dapat mempengaruhi minat pembelian konsumen.

Penelitian Aghekyan mengungkapkan hubungan yang siginifikan antara citra merek terhadap minat beli pada konsumen baju online. Semuel dan Liyanto (2014) juga menyatakan hubungan yang signifikan antara citra merek dan juga kepercayaan terhadap minat beli produk smartphone di Surabaya. Adapun menurut lien et al., (2015) juga membuktikan bahwa citra merek dan kepercayaan konsumen berpengaruh terhadap minat pembelian voucher hotel secara online.

Adapun pada penelitian ini, peneliti akan mencoba menggunakan kerangka dari penelitian terdahulu untuk diuji pada produk perekam gambar yaitu kamera dengan merek NIKON.

Untuk metode penyebaran kuesioner, peneliti menggunakan fitur direct message kepada para pengikut halaman NIKON Indonesia.

Media sosial yang terlibat dalam penelitian ini adalah instagram. Pengguna instagram mungkin saat ini hanya sebagian kecil dari pengguna facebook yang ada, tetapi interaksi pemasaran sosial terjadi lebih tinggi daripada yang ada pada facebook. Brooks (2014) menyatakan bahwa instagram mungkin hanya memiliki 150 juta pengguna aktif bulanan adalah sebagian kecil dari ukuran facebook, namun rasio interaksi untuk tulisan yang dibuat oleh 249 merek yang diteliti adalah 15 kali lebih tinggi pada instagram dari pada facebook.

\section{TINJAUAN TEORITIS}

\section{Citra Merek}

citra merek telah menjadi bagian penting untuk memperkuat nama merek di benak pelanggan. Menurut Keller (1993) citra merek dan kesadaran merek adalah dua dimensi dari pengetahuan merek. Aghekyan (2009) mendefinisikan pengetahuan merek sebagai representasi mental dari merek yang telah diterjemahkan ke dalam arti pribadi dalam memori konsumen.

Untuk memahami gambar yang dirasakan oleh konsumen, penting untuk dicatat bahwa hal ini memiliki hubungan erat dengan teori pencitraan ketika citra merek dipelajari untuk memahami perilaku orang-orang dalam mengatur keputusan pemikiran mereka 
yang struktur ini disebut citra (Keller 1993). Menurut Keller (1993) teori pencitraan mengasumsikan bahwa pengambil keputusan menggunakan tiga struktur skema pengetahuan yang berbeda untuk mengatur pemikiran mereka tentang keputusan.

Kotler et al., (1999) telah mendefinisikan secara singkat citra merek sebagai seperangkat keyakinan yang dipegang tentang merek tertentu dikenal sebagai brand image. Ferrell dan Hartline (2011) mendefinisikan citra merek sebagai keseluruhan kesan, positif atau negatif, yang konsumen miliki dalam pikiran. Kesan ini termasuk apa yang organisasi yang telah dilakukan di masa lalu, apa adalah persembahan saat ini untuk pelanggan, dan proyeksi tentang apa yang akan ia lakukan di masa mendatang. Semua aspek program pemasaran perusahaan, seperti yang dirasakan oleh pelanggan, juga akan efek kesan pelanggan.

\section{Kepercayaan Konsumen}

Kepercayaan selalu menjadi isu penting di sebagian besar ekonomi dan transaksi sosial terutama pada konteks online di mana mungkin ada banyak mengandung ketidakpastian. Mutz
(2005) menyatakan bahwa kepercayaan konsumen akan menjadi aspek penting ketika risiko yang dirasakan lebih tinggi seperti apa yang sering terjadi pada ecommerce terutama pada social media. Itu adalah sebagian besar karena kepercayaan berperan penting dalam proses adopsi e-commerce dan memiliki peran penting dalam perdagangan online.

Dengan peningkatan teknologi sosial dan interkonektivitas manusia di Internet, ada kebutuhan untuk semacam kepercayaan dan keamanan yang akan memungkinkan kedua belah pihak untuk mengurangi risiko yang dirasakan dalam transaksi (Lin, 2014). Di bidang social commerce khususnya di media platform sosial, pengguna terlibat lebih beragam. Penelitian oleh Gefen dan Straub (2004) menunjukkan bahwa orang cenderung mengurangi ketidakpastian sosial mereka di era kemajuan internet. Hal ini juga berpendapat bahwa jika sebuah situs web e-commerce menggambarkan produk atau jasa secara akurat, konsumen akan mempercayai website lebih (Hsien et al., 2009). Hal ini dapat difasilitasi oleh teknologi sosial seperti 
ulasan pelanggan, informasi dan Citra merek didefinisikan sebagai pengalaman dari orang lain dalam forum dan komunitas.

\section{Minat Pembelian}

Minat beli dikumpulkan atau berasar dari dari setiap proses pembelajaran dan proses berpikir yang sedang marak setiap dirasakan merasa pada produk tertentu. Menurut Keller (1998), minat konsumen adalah bagaimana konsumen yang paling mungkin untuk membeli merek atau seberapa besar konsumen kemungkinan untuk beralih dari satu merek ke merek lain.

Menurut Kotler (1994) niat beli ditempatkan dalam tahap evaluasi alternatif dalam proses pengambilan keputusan pembelian. Proses keputusan pembelian menjelaskan tentang bagaimana perspektif yang satu dan proses berpikir yang lain berkaitan untuk menentukan produk atau merek yang mereka ingin membeli. Tahap pertama disebut sebagai pengakuan, pencarian informasi, evaluasi alternatif, keputusan pembelian dan perilaku pasca pembelian.

\section{METODE PENELITIAN}

Kerangka Konseptual

sebuah kepercayaan yang dipercaya tentang satu merek tertentu di dalam benak konsumen (Kotler et al., 2005). Ini berarti bahwa merek diperlakukan sebagai manusia yang memiliki sikap. Sikap tersebut yang menjadi patokan tentang bagaimana orang akan menilai sikap mereka melalui beberapa tindakan seperti niat beli. Agekyan (2009) adalah menemukan bahwa citra merek memiliki pengaruh yang signifikan hanya untuk dua produk. Arista (2011) menemukan bahwa citra merek memiliki pengaruh yang signifikan tinggi terhadap niat beli. Prabowo (2014) dalam penelitiannya juga secara konsisten mendukung penelitian sebelumnya dimana citra merek secara signifikan berpengaruh terhadap niat pembelian.

Citra merek juga telah memiliki hubungan dengan kepercayaan konsumen. Semakin baik citra merek semakin tinggi konsumen akan mempercayai merek (Prabowo, 2011; Arista, 2011). Ini berarti bahwa kepercayaan konsumen juga dipengaruhi oleh perspektif konsumen terhadap merek yang didefinisikan oleh 
citra merek dagang tertentu. Lau dan Lee (2000) menyatakan bahwa karakteristik sebuah merek membangun citra merek brand relative lebih penting dalam efeknya pada kepercayaan konsumen tentang merek. Temuan oleh Semuel dan Lianto (2014) menunjukkan bahwa ada pengaruh yang signifikan dari citra merek dan niat beli. Lau dan Lee (2000) juga menemukan bahwa efek dari citra merek terhadap niat pembelian terkait secara signifikan.

Kepercayaan Konsumen didefinisikan sebagai harapan yang dimiliki oleh setiap individu atau kelompok dimana kata, janji, pernyataan lisan atau tertulis dari individu atau kelompok lain dapat diandalkan (Rotter, 1971). Ini berarti bahwa kepercayaan dipegang oleh konsumen karena merek dapat diajukan nilai dan menciptakan nilai sehingga konsumen yang percaya pada pikiran mereka.

Di bidang eCommerce, kepercayaan telah memegang aspek penting. Gefen dan Straub (2004) menyatakan bahwa pada aturan tidak mampu, konsumen mencoba untuk mengurangi ketidakpastian sosial dengan mengandalkan kepercayaan dan familiarities. Artinya, ketika bisnis yang biasa tidak dirilis ke publik kode etik mereka, konsumen langsung dapat mengenali bisnis dari familiarities dan reputasi merek.

\section{Hipotesis}

Berdasarkan penjelasan pada kerangka konseptual di atas, maka dalam penelitian ini, dapat dikembangkan hipotesis sebagai berikut:

H1 : Citra merek (brand image) secara signifikan mempengaruhi minat pembelian online

H2 : Citra Merek secara signifikan mempengaruhi kepercayaan konsumen

H3 : Kepercayaan konsumen secara signifikan mempengaruhi minat pembelian online 


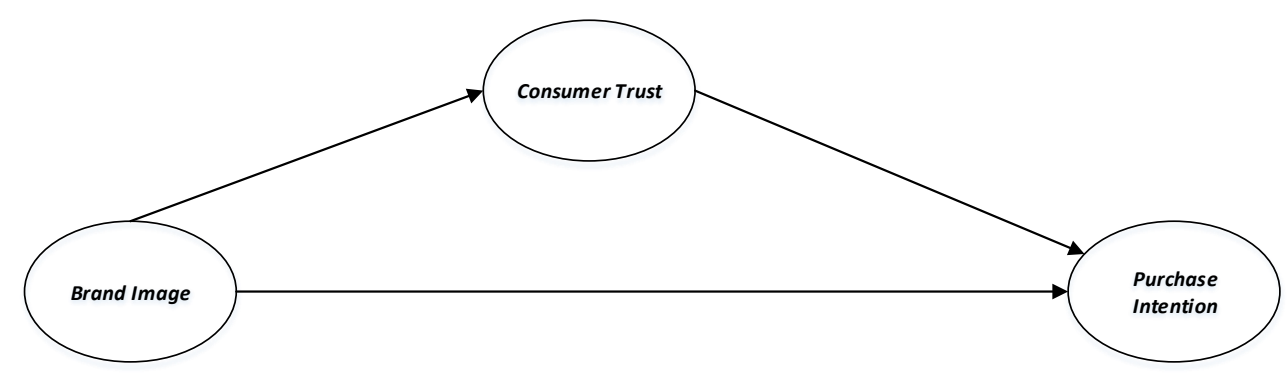

Gambar 1. Kerangka Konseptual

\section{Pengembangan Instrumen Penelitian}

Instrument penelitian ini menggunakan

skala likert dengan skala $1-5$, dimana 1

berarti sangat tidak setuju, 2 berarti tidak setuju, 3 berarti netral, 4 berarti setuju dan 5 sangat setuju.

Adapun daftar rincian pertanyaan dari masing-masing variabel dapat digambarkan dalam tabel berikut.

Tabel 1. Variabel Dan Item Penelitian

\begin{tabular}{ll}
\hline Citra Merek \\
X1.1 & $\begin{array}{l}\text { Merek ini terus memperbaiki } \\
\text { kualitasnya }\end{array}$ \\
X1.2 & Merek ini memiliki kualitas yang baik \\
X1.3 & Merek Ini sekarang sedang popular \\
X1.4 & Merek ini membuat saya tetap \\
terlihat update (gaul)
\end{tabular}

Kepercayaan Konsumen Mariné Aghekyan (2009); Arista (2011);

Z1.1 Saya percaya bahwa artikel yang ada pada instagram Nikon terpercaya

Hong and Cha (2013); Gefen and Straub (2004); Chaudhuri and Holbrook (2001); Semuel dan Lianto (2014)

Z1.2 Deskripsi produk yang dibuat pada laman Nikon sesuai

Z1.3 Nikon tahu bagaimana memperlakukan konsumen

Z1.4 Produk dari Nikon handal

\section{Minat Pembelian}

Y1.1 Saya ingin membeli produk berdasarkan rekomendasi dari laman ini

Y1.2 Saya ingin mencoba produk Nikon

Y1.3 Saya ingin tau lebih jauh terhadap produk Nikon ini
Prabowo (2014); Semuel dan Lianto (2014)
Mariné Aghekyan (2009)Prabowo (2014);

Arista (2011); Semuel dan Lianto (2014) 


\section{Populasi dan Sampel Penelitian}

Total populasi ketika penelitian itu dilaksanakan adalah sebanyak 100.050 pengikut. Seriring dengan berjalannya waktu jumlah pengikut terus bertambah dan bertambah. Dengan pertimbangan ini maka penentuan jumlah sampel ditentukan dengan menggunakan formula Machin dan Campbel dengan korelasi yang diharapkan sebesar 0.3 yang di asumsikan berdasarkan korelasi pada penelitian terdahulu (Agekyan, 2009; Arista, 2011; Prabowo, 2011). Dari hasil perhitungan didapat jumlah responden sejumlah 99 orang responden yang ditentukan secara acak sederhana.

Survei ini dilakukan di versi elektronik dengan menggunakan bantuan alat survey online Google-Docs.

Analisis data menggunakan uji statistik Generalized Structured Analysis Komponen (GSCA) yang berbasis SEM seperti yang direkomendasikan memiliki banyak keuntungan lebih dari metode lain (Gefen, 2011). Selain itu, SEM juga baik untuk penelitian eksplorasi (Chin, 1998; Gefen \& Straub, 2004), yang merupakan sifat dari penelitian ini. Metode ini juga cocok untuk menguji model baru dan teori karena dapat menjadi baik untuk penelitian konfirmatori dan eksplorasi (Gefen et al., 2011.

\section{HASIL DAN PEMBAHASAN}

\section{Validitas dan reliabilitas penelitian}

Untuk memiliki validitas isi yang tinggi, penulis melakukan tinjauan literatur substansial dalam bidang e-commerce dan sosial commerce dan dikemudikan dengan 15 siswa. Validitas penelitian ini adalah wajah dari objek yang lain dari tes ini (Gefen \& Straub, 2004).

Sumber literatur untuk setiap variabel, yang telah digunakan dalam tinjauan literatur, ditunjukkan pada Tabel 2. Dapat dilihat bahwa masing-masing konstruk menunjukkan sumber validitas dan reliabilitas yang berbeda-beda. Adapun validitas dapat dilihat dari Average Variance Extracted (AVE) dimana semua variabel memiliki nilai lebih dari 0.5 yang berarti semua item dalam masing-masing variabel adalah valid. Sedangkan reliabilitas dapat dilihat dari 
nilai alpha dimana nilai cronbach alpha

dinyatakan

reliable. berada pada nilai lebih dari 0.6 dan

Tabel 2. Inner Model, Validitas, dan Reliabilitas Variabel

\begin{tabular}{|c|c|c|c|c|c|}
\hline \multicolumn{2}{|c|}{ Variabel } & $\begin{array}{l}\text { Factor } \\
\text { Loading }\end{array}$ & CR & AVE & Alpha \\
\hline \multicolumn{4}{|c|}{ Citra Merek } & 0.811 & 0.922 \\
\hline X1.1 & $\begin{array}{l}\text { Merek ini terus memperbaiki } \\
\text { kualitasnya }\end{array}$ & 0.909 & $59.51^{*}$ & & \\
\hline $\mathrm{X} 1.2$ & $\begin{array}{l}\text { Merek ini memiliki kualitas yang } \\
\text { baik }\end{array}$ & 0.857 & $42.55^{*}$ & & \\
\hline X1.3 & Merek Ini sekarang sedang popular & 0.906 & $71.36^{*}$ & & \\
\hline X1.4 & $\begin{array}{l}\text { Merek ini membuat saya tetap } \\
\text { terlihat update (gaul) }\end{array}$ & 0.93 & $96.01^{*}$ & & \\
\hline \multicolumn{4}{|c|}{ Kepercayaan Konsumen } & 0.842 & 0.922 \\
\hline Z1.1 & $\begin{array}{l}\text { Saya percaya bahwa artikel yang ada } \\
\text { pada instagram Nikon terpercaya }\end{array}$ & 0.921 & $75.66^{*}$ & & \\
\hline $\mathrm{Z} 1.2$ & $\begin{array}{l}\text { Deskripsi produk yang dibuat pada } \\
\text { laman Nikon sesuai }\end{array}$ & 0.922 & $86.2^{*}$ & & \\
\hline $\mathrm{Z} 1.3$ & $\begin{array}{l}\text { Nikon tahu bagaimana } \\
\text { memperlakukan konsumen }\end{array}$ & 0.929 & $89.29^{*}$ & & \\
\hline Z1.4 & Produk dari Nikon handal & 0.898 & $55.46^{*}$ & & \\
\hline \multicolumn{4}{|c|}{ Minat Pembelian } & 0.842 & 0.937 \\
\hline Y1.1 & $\begin{array}{l}\text { Saya ingin membeli produk } \\
\text { berdasarkan rekomendasi dari } \\
\text { laman ini }\end{array}$ & 0.933 & $94.25 *$ & & \\
\hline Y1.2 & Saya ingin mencoba produk Nikon & 0.915 & $72.69^{*}$ & & \\
\hline Y1.3 & $\begin{array}{l}\text { Saya ingin tau lebih jauh terhadap } \\
\text { produk Nikon ini }\end{array}$ & 0.928 & $74.01^{*}$ & & \\
\hline
\end{tabular}

\section{Pengukuran outer Model}

Pengukuran outer model digunakan untuk mengukur bagaimana spesifikasi hubungan antara indicator/ item terhadap variabel atau kontruk tertentu (Hair et al., 2010). Loading factor yang ditunjukkan pada tabel $\mathrm{di}$ atas menunjukkan item yang paling terlihat dalam setiap variabel. Loading factor ini juga dapat diartikan sebagai nilai korelasi antara item terhadap variabel. Dapat dilihat pada variabel Citra Merek, sebagian besar item dilihat dari item X1.4 yaitu "merek ini membuat saya tetap terlihat update (gaul)" dengan nilai estimasi 0,93 . Variabel Kepercayaan sebagian besar terlihat dari barang Z1.2 yaitu “Deskripsi produk 
yang dibuat pada laman Nikon sesuai" diperkirakan sebanyak 0,22. Minat pembelian sebagian besar oleh item Y.1.1 yaitu "saya ingin membeli produk Nikon berdasarkan rekomendasi dari laman ini" diperkirakan sebanyak 0,933.

\section{Pengukuran inner model}

Hasil pengukuran inner model bertujuan untuk mengetahui hubungan antar variabel. Jadi pada dasarnya inner model digunakan untuk menentukan spesifikasi hubungan antar variable/ konstruk.

Dari tabel 3 dibawah dapat diketahui bahwa kriteria kelayakan model diketahui sebesar 0.757 yang artinya model yand dibangun dapat menjelaskan hubungan antara variabel eksogen dan endogen sebesar $75 \%$. Hasil ini mencerminkan bahwa model sangat baik dalam menjelaskan hubungan

Tabel 3 Model Fit

\begin{tabular}{ccc}
\hline \multicolumn{3}{c}{ Model Fit } \\
\hline FIT & 0.757 \\
AFIT & 0.751 \\
NPAR & 39 \\
\hline
\end{tabular}

Tabel 4 Hasil Analisis Jalur GESCA

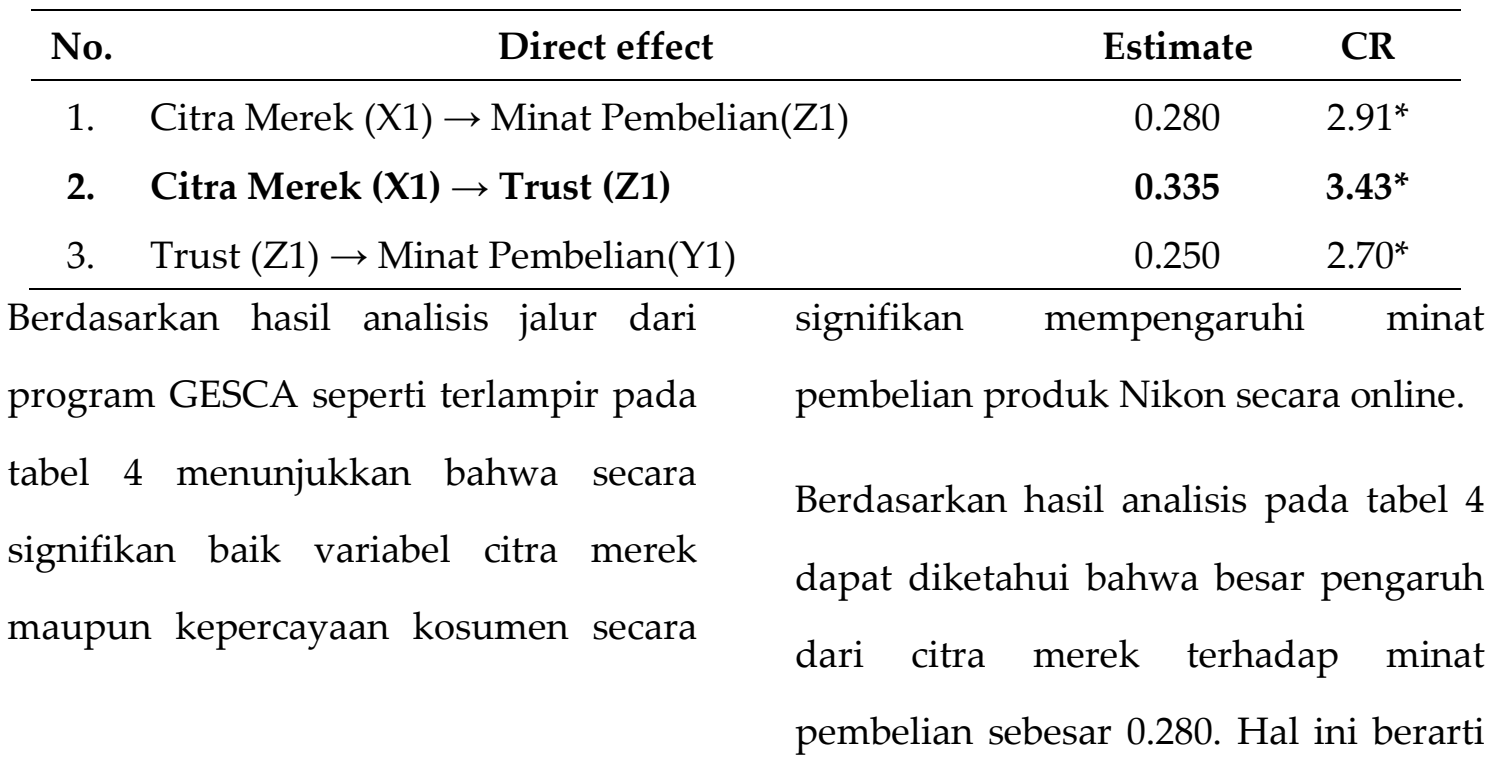


citra merek hanya dipertimbangkan oleh konsumen sebesar $28 \%$ saja ketika konsumen berminat untuk membeli produk dari halaman Nikon.

Dari hasil tersebut juga diketahui bahwa besar pengaruh dari citra merek terhadap kepercayaan konsumen sebesar 0.355 . Hal ini berarti citra merek dianggap sebagai hal yang dipertimbangkan sebesar $35 \%$ oleh konsumen sebagai komponen untuk mempercayai suatu merek.

Hal juga diungkapkan oleh tabel 4 diatas adalah besar pengaruh dari kepercayaan konsumen terhadap minat pembelian sebesar 0.250 . Hal ini berarti bahwa ketika konsumen ingin membeli produk, mereka mempertimbangan kepercayaan mereka sendiri terhadap produk sebesar 25\% ketika akan membeli produk secara online.

Jika dilihat dari hasil tersebut, dinyatakan bahwa pengaruh citra merek terhadap kepercayaan konsumen adalah paling tinggi dibandingkan dengan lain. Hal ini menunjukkan bahwa ketika konsumen percaya akan suatu produk, konsumen sangat mempertimbangkan citra merek dari produk itu sendiri.
Untuk mengetahui pengaruh tidak langsung dari citra merek terhadap minat pembelian melalui kepercayaan konsumen, maka peneliti mencoba hasil dari pengaruh tersebut untuk kemudian diolah melalui sobel calculator dan didapat hasil sebagai berikut.

Tabel 5 Hasil Sobel Calculator

\begin{tabular}{ll}
\hline Estimates & CR \\
0.084 & 2.10159 \\
\hline
\end{tabular}

Berdasarkan perhitungan pada tabel 5 tersebut terlihat bahwa pengaruh tidak langsung dari citra merek terhadap minat pembelian melalui kepercayaan produk hanya sebesar $8.4 \%$.

Hal ini menunjukkan bahwa citra merek sendiri sudah cukup untuk membuat konsumen untuk berminat untuk membeli produk secara online. Hal ini bisa dilihat dari hasil perekaman data pada jumlah pengikut dari halaman fans Nikon Indonesia di instagram lebih besar jika dibandingkan dengan merekmerek yang lain. Hal ini dapat dibuktikan dengan rekaman data berikut yang dikumpulkan oleh peneliti pada bulan November 2016. 


\begin{tabular}{|l|r|}
\hline Nikon_id & 128.000 \\
\hline Canon Indonesia & 15.200 \\
\hline Nikon & $\mathbf{1 6 8 . 0 0 0}$ \\
\hline Sonyindonesia & 54.100 \\
\hline $\begin{array}{l}\text { Olympus } \\
\text { Indonesia }\end{array}$ & 14.600 \\
\hline Lumix Indonesia & 4.667 \\
\hline
\end{tabular}

\section{KESIMPULAN DAN SARAN}

Penelitian ini mencoba mengetahui tentang bagaimana interaksi pengguna mengenai pengaruh citra merek dan juga kepercayaan konsumen terhadap minat pembelian yang terjadi pada konsumen online khusunya yang ada pada platform media sosial. Peneliti menggunakan beberapa teori untuk menjelaskan penggunaan model yang diajukan pada beberapa penelitian terdahulu dengan menggunakan model penelitian yang melibatkan tiga konstruk dengan menggunakan alat analisis GSCA. Hasil dari penelitian ini menunjukkan bahwa terdapat hubungan yang berarti antara citra merek terhadap minat pembelian. Hasil output juga menunjukkan bahwa terdapat pengaruh langsung antara kepercayaan konsumen terhadap minat pembelian. Hasil tidak langsung juga menunjukkan bahwa secara tidak langsung citra merek akan menguatkan kepercayaan konsumen yang juga akan menambah minat pembelian.

Kontribusi utama dari penelitian ini adalah untuk menambah warna dalam khasanah keilmuan terutamanya pada perilaku konsumen online khususnya pada platform media sosial. Penelitian ini menganjurkan kepada para pengguna media sosial, khususnya yang digunakan untuk keperluan komersial untuk lebih lebih konsisten dalam meningkatkan kualitas citra merek dan juga kepercayaan konsumen pada laman mereka. Dengan adanya konsistensi ini maka diharapkan akan terus menciptakan peluang strategi pemasaran yang dapat menguntungkan baik untuk vendor maupun konsumen.

\section{DAFTAR PUSTAKA}

Adi. 2016. Are you making these online survey mistakes. diakses September 2016:

https://www.questionpro.com/blog/ 6-problems-with-online-surveysand-how-to-avoid-them/

Aghekyan, Marine. 2009. The role of product brand image and online store image on Perceived risks and online purchase intentions. Alabama: Auburn Universities 
Aghekyan, Fosrthye, \& Kwon. 2012. The role of product brand image and online store image on perceived risks and online purchase intentions for apparel. Journal of Retailing and Consumer Services 19 (2012) 325-331

Arista, Elisabeth D. 2011. Analisis pengaruh iklan, brand trust dan brand image terhadap minat beli konsumen telkom speedy di kota semarang. Diponegoro University

Chaudhuri, A. And Holbrook, H.B. 2001. The chain of effect from brand trust and brand affect to brand performance: the role of branf loyalty. Journal of Marketing, Vol. 65 No. 2.

Chin, W. W. 1998. Issues and opinion on structural equation modeling (Editorial). MIS Quarterly, 1. Diunduh dari: http://search.ebscohost.com/login.asp $x$ ?direct=true\& $d b=$ buh\&AN $=345479 \&$ $\underline{\text { site }=\text { ehost-live }}$

Ferrell and hatrline. 2011. Marketing Strategy. Ohio, mason: South-Western Cengage Learning

Gefen, D., \& Straub, D. W. (2004). Consumer trust in $\mathrm{B} 2 \mathrm{C}$ e-commerce and the importance of social presence: Experiments in e-products and $e$ services. Omega, 32(6), 407-424. http://dx.doi.org/10.1016/j.omega.200 $\underline{4.01 .006}$

Keller, K. L. (1993). Conceptualizing, measuring, and managing customerbased brand equity. Journal of Marketing, 57(1), 1-22.

Kotler et al., 1999. Principles of marketing. New York: Prentice Hall
Kotler, Philip dan Keller, Kevin Lane. 2005. Manajemen Pemasaran, Indeks, Jakarta

Latan, Hengki. 2014. GESCA: Teori, Konsep, dan Aplikasi. Bandung: Satu Nusa

Lau, G.T., and Lee, S.H. 2000. Consumer Trust in Brand and the Link to Brand Loyalty. Journal of Market Focused Management. 4, pp. 341-370

Lin, K. Y., \& Lu, H. P. 2011. Why people use social networking sites: an empirical study integrating network externalities and motivation theory. Computers in Human Behavior, 27(3), 1152-1161.

Ming-Hsien, Y., Chandlrees, N., Binshan, L., \& Hung-Yi, C. (2009). The effect of perceived ethical performance of shopping websites on consumer trust. Journal of Computer Information Systems, 50(1), 15-24

Mutz, D. C. 2005. Social trust and ecommerce: Experimental evidence for the effects of social trust on individuals' economic behavior. Public Opinion Quarterly, 69(3), 393-416. http://dx.doi.org/10.1093/poq/nfi029

Prabowo, Riefky. 2014. Analisis pengaruh iklan, brand trust dan brand imageterhadap minat beli konsumen mastin ekstrak kulit manggis di kota Malang. University of Brawijaya malang

Rotter, J.B., 1971. Generalized expectancies for interpersonal trust. American psychologist, 26(5), p.443. 
Semuel, Hatane \& Lianto, Adi S. 2014. Analisis ewom, brand image, brand trust dan minat beli produk smartphone di Surabaya. Jurnal manajemen pemasaran, vol. 8, no. 2, October 2014

Statista. 2015. Leading social networks worldwide as of March 2015, ranked by number of active users (in millions). Statista.com, retrieved on 16/3/2015 from

[http://www.statista.com/statistics/2 72014/global-social-networksranked-by-number-of-users/]

Tenenhaus M. 2008. Component-based Structural Equation Modelling, [Online],

http://www.hec.fr/heccontent/down load/4797/115324/version/2/file/CR8 87TENENHAUS.pdf, 2008. 